\title{
Effects of human chorionic gonadotrophin on contractile activity of steroid-primed pig myometrium in vitro
}

\author{
B. Flowers*, A. J. Ziecik $†$ and E. V. Caruolo \\ Department of Animal Science, North Carolina State University, Raleigh, NC 27695-7621, USA
}

\begin{abstract}
Summary. We examined the effects of (a) oestrogen and progesterone on concentrations of luteinizing hormone/human chorionic gonadotrophin $(\mathrm{LH} / \mathrm{hCG}$ ) receptors in uterine smooth muscle in vivo and (b) hCG on spontaneous myometrial contractions in vitro. Ovariectomized gilts received $2 \mathrm{ml}$ corn oil (control; $n=5$ ), $2 \mathrm{mg}$ oestradiol benzoate ( $n=6$ ) or $20 \mathrm{mg}$ progesterone $(n=5)$ for 5 days. Gilts were hysterectomized $8 \mathrm{~h}$ after the last injection and longitudinal sections of myometrium were incubated in modified Krebs' solution with 0 or $10 \mathrm{i}$.u. of hCG $(n=10 /$ gilt $)$ for $4 \mathrm{~h}$ at $37^{\circ} \mathrm{C}$ in $95 \%$ $\mathrm{O}_{2}: 5 \% \mathrm{CO}_{2}$. After incubation, myometrial sections were placed in a tissue chamber perfused with Krebs' solution and mechanical activity was recorded for $30 \mathrm{~min}$. Cell membrane fractions were prepared from myometrial tissue not used for in-vitro studies and analysed for $\mathrm{LH} / \mathrm{hCG}$ receptors. Treatment with oestradiol benzoate increased $(P<0.01)$ the number of $\mathrm{LH} / \mathrm{hCG}$-binding sites compared with gilts receiving corn oil or progesterone. Incubation of myometrium with hCG reduced $(P<0.01)$ the frequency and amplitude of spontaneous uterine contractions in gilts treated with oestradiol benzoate. In contrast, hCG had no effect $(P>0.05)$ on the pattern of myometrial contractions in gilts given corn oil or progesterone. These results indicate that oestradiol promotes the synthesis of $\mathrm{LH} / \mathrm{hCG}$ receptors in pig myometrium and incubation of oestrogen-primed tissue with hCG has a quiescent effect on myometrial contractility.
\end{abstract}

Ke words: LH; receptors; myometrium; uterine contractions; chorionic gonadotrophin; pig

\section{Introduction}

Uterine contractions are involved in a number of important reproductive processes (Finn \& Porter, 1975; Huzar, 1983), including gamete transport (Blandau, 1969; Hawk, 1973; Hawk \& Cooper, 1974), intrauterine migration of embryos (Pope et al., 1982) and parturition (Taverne, 1982; Challis \& Lye, 1986). Contractions of uterine smooth muscle during these physiological events are regulated by steroid hormones (Lye \& Porter, 1978; Lye et al., 1983b; Porter \& Lye, 1983), prostaglandins (Rexroad \& Barb, 1975; Gimeno et al., 1979; Lye \& Challis, 1982; Wainmann et al., 1988), oxytocin (Liggins et al., 1973; Cahilletal., 1976), relaxin (Schwabe et al., 1978; Szlachter etal., 1980; Porter et al., 1981) and biogenic amines (Rexroad \& Barb, 1978).

Recently, specific high-affinity, low-capacity binding sites for luteinizing hormone/human chorionic gonadotrophin $(\mathrm{LH} / \mathrm{hCG}$ ) were identified in the myometrium of pigs (Ziecik et al., 1986) and rabbits (Jensen \& Odell, 1988). The presence of $\mathrm{LH} / \mathrm{hCG}$ receptors in the myometrium raises the intriguing possibility that LH may have a direct effect on uterine function in addition to its indirect actions associated with the ovarian production of steroid hormones. However, neither the

\footnotetext{
*Reprint requests: Dr B. Flowers, 211A Polk Hall, Box 7621, North Carolina State University, Raleigh, NC 27695-7621. USA.

†Present address: Department of Reproductive Endocrinology, Centre of Agrotechnology and Veterinary Polish Academy of Sciences, Olsztyn, Poland, 10-718.
} 
physiological significance nor hormonal regulation of myometrial $\mathrm{LH} / \mathrm{hCG}$ receptors has been established. Therefore, in the present study, we examined the effects of (a) oestrogen and progesterone on the concentration of myometrial $\mathrm{LH} / \mathrm{hCG}$ receptors in vivo and (b) hCG on the contractility of steroid-primed uterine smooth muscle in vitro.

\section{Materials and Methods}

Animals. Crossbred gilts (Yorkshire $\times$ Landrace $\times$ Duroc, $127-136 \mathrm{~kg}$ ) were ovariectomized after sexual maturity and 3 months before the experiment began. They were housed individually in $1.2 \times 1.3 \mathrm{~m}$ pens and received $2.8 \mathrm{~kg}$ of a $14 \%$ crude-protein, maize soyabean meal diet per day during the study. Water was provided ad libitum.

Experimental design. Gilts received daily i.m. injections of either $2 \mathrm{ml}$ corn oil (control; $n=5$ ), $2 \mathrm{mg}$ oestradiol benzoate $(n=6)$ or $20 \mathrm{mg}$ progesterone $(n=5)$ for 5 consecutive days. Oestradiol benzoate and progesterone were purchased from Sigma Chemical Company, St Louis, MO. Corn oil $(2 \mathrm{ml})$ was the vehicle for all steroid hormones.

Blood samples were collected from a jugular vein via venepuncture $4 \mathrm{~h}$ before the first injection and $8 \mathrm{~h}$ after the last injection of each treatment. Blood samples were allowed to clot at $4^{\circ} \mathrm{C}$ and serum was collected by decanting the supernatant after refrigerated centrifugation at $1200 \mathrm{~g}$ for $20 \mathrm{~min}$. Serum was stored at $-20^{\circ} \mathrm{C}$.

Gilts were hysterectomized $8 \mathrm{~h}$ after receiving their last injection on Day 5. Anaesthesia was induced with $1 \mathrm{~g}$ of sodium thiopental (i.v.) and maintained with a closed-circuit system of halothane, nitrous oxide and oxygen. After hysterectomy, uteri were transported to the laboratory on ice. Myometrium was separated from endometrium by gentle scraping. Longitudinal sections of myometrium ( $2 \mathrm{~mm}$ wide $\times 20 \mathrm{~mm}$ long; $55 \pm 0.02 \mathrm{mg}$ ) were removed from 5 locations equidistant between the utero-tubal junction and the cervix on each uterine horn $(n=10 /$ gilt). Each of these myometrial strips was further divided into 2 sections ( $2 \mathrm{~mm}$ wide $\times 10 \mathrm{~mm}$ long; $25 \pm 0.03 \mathrm{mg}$ ) and incubated in modified Krebs' solution with either 0 or 10 i.u. hCG $(n=10 /$ gilt/in-vivo treatment $)$ for $4 \mathrm{~h}$ at $37^{\circ} \mathrm{C}$ in $95 \% \mathrm{O}_{2}: 5 \%$ $\mathrm{CO}_{2}$. Incubation conditions were selected to promote maximum binding of hCG to myometrial receptors (Ziecik et al., 1986). The ionic composition of the modified Krebs' solution was $25 \mathrm{mmol} \mathrm{Ca}{ }^{2+} / 1,134 \mathrm{mmol} \mathrm{Cl}^{-} / 1,15 \cdot 5 \mathrm{mmol}$

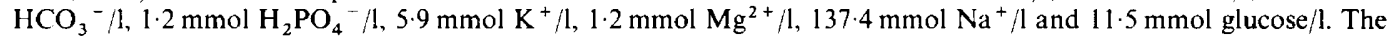
solution was equilibrated with a mixture of $95 \% \mathrm{O}_{2}$ and $5 \% \mathrm{CO}_{2}$.

Immediately after incubation, myometrial strips were suspended in $3.8-\mathrm{ml}$ tissue chambers perfused with modified Krebs' solution at $37^{\circ} \mathrm{C}$. The Kreb's solution in the chamber was exposed continuously to a mixture of $95 \% \mathrm{O}_{2}: 5 \%$ $\mathrm{CO}_{2}$. Isometric contractions were recorded by suspending uterine strips from an isometric transducer (Narco Bio-systems, Inc., Houston, TX), which was coupled to a physiological pen recorder (Myograph F-60; Narco Biosystems, Inc., Houston, TX); initial resting tension was adjusted to $500 \mathrm{mg}$. Mechanical activity was recorded for $30 \mathrm{~min}$ after the muscle began to contract spontaneously and showed a stable pattern of rhythmic contractions ( $\sim 15 \mathrm{~min})$. At the end of each recording period, myometrial strips were exposed to $0.09 \mathrm{M}-\mathrm{KCl}$. Data from strips not producing a contractile response to $\mathrm{KCl}$ were not included in the statistical analyses. Before the addition of $\mathrm{KCl}, 24$ of the myometrial strips from gilts treated with oestradiol benzoate in vivo and hCG in vitro were selected at random and exposed to $0.9 \mu \mathrm{M}$ prostaglandin (PG) F-2 $\alpha$ (Lutalyse, The UpJohn Co., Kalamazoo, MI). Mechanical activity was recorded for an additional $30 \mathrm{~min}$.

$\boldsymbol{L} H / h C G$ receptor binding analyses. Myometrium not used for in-vitro studies was analysed for $\mathrm{LH} / \mathrm{hCG}$ receptors. Cell membrane fractions were prepared according to the procedures of Ziecik et al. (1986). Protein and DNA contents of the receptor preparation were determined according to the methods of Lowry et al. (1951) and Burton (1956), respectively. The assay used for measurement of membrane-bound, myometrial LH/hCG receptors has been described and validated previously (Ziecik et al., 1986; Pomp et al., 1988). Specific activities of $\left[{ }^{125} \mathrm{I}\right]$ iodo-hCG (CR-121, 13450 i.u./mg) were determined by self displacement in a radioligand receptor assay (Ketelslegers et al., 1975) and averaged $45 \mu \mathrm{Ci} / \mu \mathrm{g}$. The mean maximum binding of iodinated $\mathrm{hCG}$ preparations in the presence of excess receptor was $61 \cdot 3 \%$. Non-specific binding was measured by the addition of $1 \mu \mathrm{g}$ unlabelled hCG and was $<2 \%$ of the total ${ }^{125} I$ added. Concentrations of unoccupied binding sites and affinity constants $\left(K_{\mathrm{a}}\right)$ were determined by Scatchard analysis (Scatchard, 1949). Seven subsaturating quantities of unlabelled hCG $(0.01-5 \mathrm{ng})$ were used for each receptor preparation. Sensitivity of the receptor assay was $0.15 \mathrm{fmol} / \mathrm{mg}$ protein.

Hormone analyses. Serum concentrations of LH were determined by radioimmunoassay (Stevenson et al., 1981; Armstrong \& Britt, 1987). Purified LH (LER-786-3) was used for preparation of the radioiodinated antigen and standard. Assay sensitivity was $0.2 \mathrm{ng} / \mathrm{ml}$ and intra-assay coefficient of variation for a single assay was $7.5 \%$.

A radioimmunoassay procedure described by Guthrie \& Bolt (1983) and modified by Esbenshade \& Britt (1985) was used to determine concentrations of follicle-stimulating hormone (FSH). Anti-pFSH (USDA-10-1010), ${ }^{125}$ Ilabelled pFSH (USDA-FSH-PPI) and pFSH (USDA-FSH-B-I) were used as the first antibody, radiolabelled ligand and standard, respectively. Intra-assay coefficient of variation for a single assay was $9 \cdot 7 \%$. Assay sensitivity was $6 \mathrm{ng} / \mathrm{ml}$.

Serum concentrations of oestradiol-173 and progesterone were determined by radioimmunoassay described by Cox \& Britt (1982) and Stevenson et al. (1981), respectively. For oestradiol-173, assay sensitivity was $2 \mathrm{pg} / \mathrm{ml}$ and the intra-assay coefficient of variation was $8 \%$. Cross-reactivity of the oestradiol- $17 \beta$ antiserum used in the radioimmunoassay with oestradiol benzoate was $97.3 \%$. For progesterone, assay sensitivity was $0.2 \mathrm{ng} / \mathrm{ml}$ and the intra- 
assay coefficient of variation was $7 \cdot 7 \%$. All samples were quantified in a single radioimmunoassay for each steroid hormone.

Statistical analysis. Treatment effects on myometrial contractions were evaluated by three criteria: amplitude (mg), frequency (number/min) and duration (s) (Rexroad \& Barb, 1975; Kawarabayashi et al., 1989). Data on contractions were analysed by analysis of variance procedures for a split-split-slot design using the General Linear Models procedure of the Statistical Analysis System (Snedecor \& Cochran, 1980). The main plot was in-vivo treatment (corn oil, oestradiol benzoate or progesterone); the subplot was in-vitro treatment ( 0 or 10 i.u. hCG) and the sub-subplot was uterine location (1-10). There were no effects $(P>0 \cdot 05)$ of uterine location or its interactions and, therefore, data were reanalysed using a statistical model for a split-plot design (Snedecor \& Cochran, 1980). A significant in-vivo $\times$ in-vitro treatment interaction was present $(P<0.05)$. This model was modified to compare differences between myometrial strips receiving 0 or 10 i.u. of hCG within each of the in-vivo treatments (Steel \& Torrie, 1980).

Receptor concentrations and hormone data were analysed by least-squares analysis of variance procedures. Treatment mean comparisons for all data were made using Tukey's standardized range test (Steel \& Torrie, 1980).

\section{Results}

\section{LH/hCG receptors}

Gilts receiving oestradiol benzoate for 5 consecutive days had higher $(P<0.01)$ concentrations of myometrial $\mathrm{LH} / \mathrm{hCG}$ receptors than females given corn oil or progesterone. Affinity constants $\left(\mathrm{K}_{\mathrm{a}}\right)$ for receptors were not different $(P>0.05)$ among treatments and averaged $7.8 \times 10^{10} / \mathrm{mol}$, $8.5 \times 10^{10} / \mathrm{mol}$ and $7 \cdot 7 \times 10^{10} / \mathrm{mol}$ for control gilts and those treated with oestradiol benzoate and progesterone, respectively.

\section{Hormone concentrations}

Concentrations of LH, FSH and progesterone were similar $(P>0.05)$ in all gilts before the onset of the experiment (time, $-4 \mathrm{~h}$; data not shown). Mean values were $2.0 \mathrm{ng} / \mathrm{ml}, 25 \cdot 1 \mathrm{ng} / \mathrm{ml}$ and $1 \cdot 2 \mathrm{ng} / \mathrm{ml}$ for $\mathrm{LH}, \mathrm{FSH}$ and progesterone, respectively. Concentrations of oestradiol were below the sensitivity of the assay (non-detectable). In gilts that had received corn oil, oestradiol benzoate or progesterone for 5 days, LH and FSH were not significantly different among treatments (Table 1), but administration of progesterone and oestradiol benzoate resulted in substantial increases $(P<0.01)$ in serum concentrations of progesterone and oestradiol-17 $\beta$, respectively. Serum concentrations of progesterone increased from 2.0 to $9.4 \mathrm{ng} / \mathrm{ml}$ in gilts receiving progesterone. Similarly, in females treated with oestradiol benzoate, oestradiol- $17 \beta$ concentrations increased from non-detectable concentrations $(<2 \mathrm{pg} / \mathrm{ml})$ before injections to $131.4 \mathrm{pg} / \mathrm{ml}$ on the final day of steroid administration.

Table 1. Mean concentrations of luteinizing hormone/human chorionic gonadotrophin $(\mathrm{LH} / \mathrm{hCG})$ receptors in porcine myometrium and serum concentrations of progesterone, oestradiol-17 $\beta$, LH and follicle-stimulating hormone (FSH) in ovariectomized gilts treated with corn oil (control), oestradiol benzoate or progesterone

\begin{tabular}{lcccc}
\hline & Control & $\begin{array}{c}\text { Oestradiol } \\
\text { benzoate }\end{array}$ & Progesterone & Pooled s.e. \\
\hline LH/hCG receptors & & & & \\
$\quad$ fmol/mg protein & $0 \cdot 19$ & $0 \cdot 71^{*}$ & $0 \cdot 22$ & $0 \cdot 04$ \\
$\quad$ fmol/mg DNA equivalent & $0 \cdot 38$ & $1 \cdot 49^{*}$ & $0 \cdot 54$ & $0 \cdot 14$ \\
Progesterone $(\mathrm{ng} / \mathrm{ml})$ & $1 \cdot 4$ & $1 \cdot 2$ & $9 \cdot 4^{*}$ & $1 \cdot 4$ \\
Oestradiol-17ß $(\mathrm{pg} / \mathrm{ml})$ & $7 \cdot 2$ & $131 \cdot 4^{*}$ & $7 \cdot 8$ & $15 \cdot 7$ \\
LH $(\mathrm{ng} / \mathrm{ml})$ & $1 \cdot 8$ & $0 \cdot 8$ & $1 \cdot 1$ & $0 \cdot 4$ \\
FSH $(\mathrm{ng} / \mathrm{ml})$ & $27 \cdot 2$ & $15 \cdot 1$ & $21 \cdot 3$ & $4 \cdot 8$ \\
\hline
\end{tabular}

*Values significantly different from control, $P<0.01$. 
Table 2. Mean ( \pm s.e.) frequency, amplitude and duration of spontaneous contractions in porcine myometrium incubated with 0 or 10 i.u. human chorionic gonadotrophin (hCG) from gilts given corn oil (control), oestradiol benzoate or progesterone for 5 consecutive days. $(n=$ number of myometrial sections)

\begin{tabular}{|c|c|c|c|c|}
\hline Treatment & $\begin{array}{l}\text { Frequency } \\
\text { (no. min) }\end{array}$ & $\begin{array}{l}\text { Amplitude } \\
\text { (mg) }\end{array}$ & $\begin{array}{l}\text { Duration } \\
\text { (s) }\end{array}$ & $n$ \\
\hline \multicolumn{5}{|l|}{ Control } \\
\hline 0 & $2 \cdot 4 \pm 0 \cdot 3$ & $142 \cdot 2 \pm 10 \cdot 1$ & $25 \cdot 1 \pm 3 \cdot 0$ & 47 \\
\hline $10 \mathrm{i.u.hCG}$ & $2 \cdot 1 \pm 0 \cdot 2$ & $139.2 \pm 9.8$ & $28 \cdot 6 \pm 4 \cdot 1$ & 48 \\
\hline \multicolumn{5}{|l|}{ Oestradiol benzoate } \\
\hline 0 & $1.8 \pm 0.2$ & $371 \cdot 7 \pm 10 \cdot 3$ & $34 \cdot 8 \pm 4 \cdot 1$ & 59 \\
\hline 10 i.u. hCG & $0.3 \pm 0.1 *$ & $235 \cdot 3 \pm 14 \cdot 1^{*}$ & $42 \cdot 7 \pm 5 \cdot 1$ & 58 \\
\hline $\begin{array}{l}10 \text { i.u. hCG }+ \\
\text { prostaglandin F-2 } 2\end{array}$ & $1 \cdot 4 \pm 0.4$ & $354 \cdot 3 \pm 21 \cdot 5$ & $47 \cdot 1 \pm 5 \cdot 7$ & 24 \\
\hline \multicolumn{5}{|l|}{ Progesterone } \\
\hline 0 & $I \cdot 2 \pm 0 \cdot 2$ & $51.9 \pm 6.1$ & $47 \cdot 3 \pm 4 \cdot 2$ & 46 \\
\hline 10 i.u. hCG & $0.8 \pm 0 \cdot 3$ & $47.4 \pm 8.4$ & $58 \cdot 3 \pm 5 \cdot 6$ & 49 \\
\hline
\end{tabular}

*Values significantly different from strips not incubated with hCG $(0)$ in control gilts and those treated with oestradiol benzoate or progesterone, $P<0.01$.

(a)

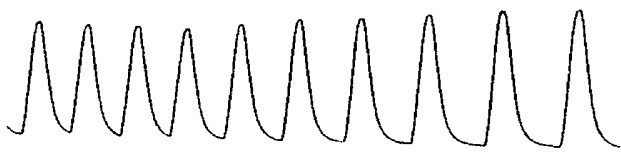

(b)

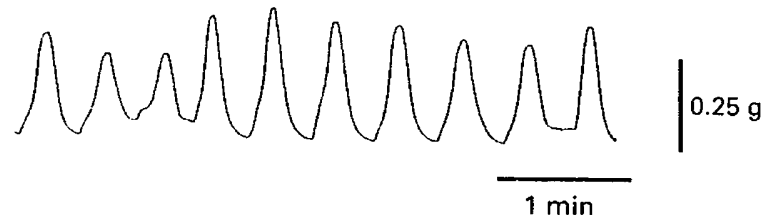

Fig. 1. Patterns of spontaneous contractions of porcine myometrium from gilts receiving corn oil in vivo and (a) 0 or (b) $10 \mathrm{i} . \mathrm{u}$. human chorionic gonadotrophin in vitro.

\section{Myometrial contraction}

Incubation with hCG in vitro had no effect $(P>0.05)$ on the amplitude, frequency or duration of myometrial contractions in gilts given corn oil or progesterone, but hCG reduced $(P<0.01)$ the frequency and amplitude of spontaneous contractions in gilts treated with oestradiol benzoate (Table 2 and Figs 1, 2 and 3). Mechanical activity of uterine smooth muscle incubated with hCG in gilts receiving oestradiol benzoate increased $(P<0.01)$ after administration of PGF-2 $\alpha$ and was similar $(P>0.05)$ to the pattern observed from myometrium not exposed to hCG.

\section{Discussion}

Results from the present study demonstrate that oestradiol is involved in the regulation of $\mathrm{LH} /$ hCG-binding sites in pig myometrium. This is evident in that concentrations of myometrial $\mathrm{LH} / \mathrm{hCG}$ 
(a)

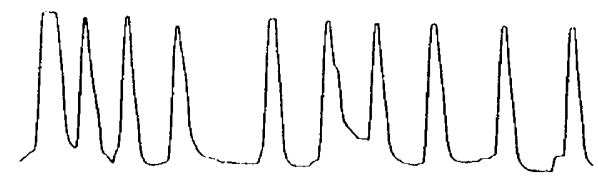

(b)

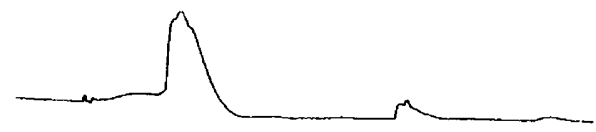

(c)

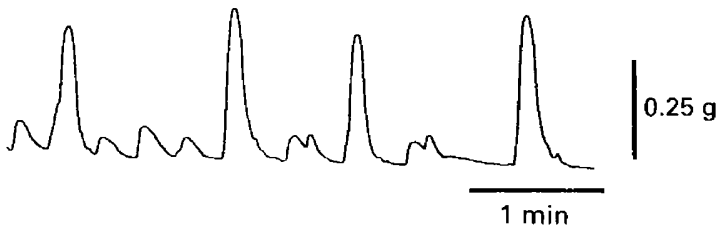

Fig. 2. Patterns of spontaneous contractions of porcine myometrium from gilts receiving oestradiol benzoate in vivo and (a) 0 or (b) 10 i.u. human chorionic gonadotrophin (hCG) in vitro; (c) stimulation by prostaglandin F-2 $\alpha$ on oestrogen-primed uterine smooth muscle incubated with 10 i.u. hCG.

(a)

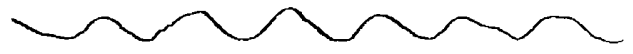

(b)

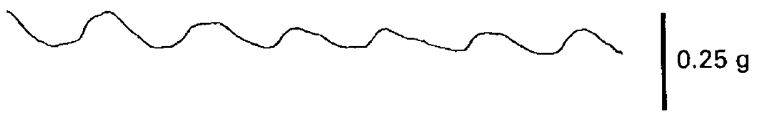

$1 \mathrm{~min}$

Fig. 3. Patterns of spontaneous contractions of porcine myometrium from gilts receiving progesterone in vivo and (a) 0 or (b) 10 i.u. human chorionic gonadotrophin in vitro.

receptors were 3-4-fold greater in ovariectomized gilts given oestradiol benzoate than in their control counterparts. Similar stimulatory effects of oestrogens on $\mathrm{LH}$ receptor concentrations have been observed in corpora lutea (Garverick et al., 1982) and granulosa cells (Richards et al., 1976; Hsueh et al., 1984). Thus, even though a number of substances are probably involved in the regulation of gonadotrophin receptors, enhancement of $\mathrm{LH} / \mathrm{hCG}$ receptor concentrations may be a fairly ubiquitous response of female reproductive tissues to oestrogenic compounds. 
From our results, one would expect changes in concentrations of myometrial LH/hCGbinding sites during the oestrous cycle to reflect the secretory pattern of oestradiol. However, Ziecik et al. (1986) reported that myometrium from the late follicular phase (Days 18-20) contained fewer $\mathrm{LH} / \mathrm{hCG}$ receptors than myometrium from the luteal phase. Pigs in our study were given oestradiol benzoate or progesterone for 5 days prior to the quantification of $\mathbf{L H} /$ hCG receptors. Because of hormone concentrations during the oestrous cycle (Van de Wiel et al., 1981), females in the study of Ziecik et al. (1986) were probably exposed to lower concentrations of oestradiol for a shorter period and higher concentrations of progesterone over a longer period than gilts used in our study. Thus, differences in the magnitude and duration of steroid hormone exposure between the two studies could explain the observed variation in concentrations of myometrial receptors.

In terms of functional significance, our results demonstrate that incubation of myometrium from oestrogen-primed tissue with hCG produced a quiescent effect on the spontaneous mechanical activity of uterine smooth muscle. Modifications in myometrial contraction usually are the result of changes in frequency and amplitude of individual contractions (Taverne, 1982; Challis \& Lye, 1986). While reductions in both these variables were observed in the present study, the quiescent effect of hCG primarily was due to a decrease in frequency. This is shown by the frequency of spontaneous contractions being reduced by $83 \%$, whereas amplitude decreased only $36 \%$ in response to incubation with hCG. Whether this quiescence was due to direct action of hCG on oestrogen-primed muscle cells or was mediated via the production of some other substance is not known.

PGF-2 $\alpha$ stimulated spontaneous contractions and essentially overcame the quiescent effects of hCG on oestrogen-primed myometrium in vitro. Stimulation of myometrial contractions by prostaglandins in the presence of compounds that induce relaxation of uterine smooth muscle is a common phenomenon in vivo (Lye \& Challis, 1982; Challis \& Lye, 1986). Consequently, it has been suggested that many substances which influence myometrial activity exert their effects via prostaglandin synthesis and release (Hawk, 1975; Lye et al., 1983a). Accordingly, Lye et al. (1983a) provided evidence that the biphasic contractile response of ovine myometrium to oestrogens was associated with the production of prostaglandins. Potential relationships between oestrogens, $\mathrm{LH} / \mathrm{hCG}$ receptors and prostaglandins in the hCG-induced quiescence of myometrial contractions observed in our study remain to be determined. However, it appears that the mechanical activity of the porcine uterus is controlled by complex mechanisms involving a number of different factors.

In summary, oestradiol benzoate increased the concentration of myometrial $\mathrm{LH} / \mathrm{hCG}$ receptors in vivo. Incubation of oestrogen-primed tissue with hCG had a quiescent effect on uterine smooth muscle contractions in vitro. Thus, it seems plausible that LH may be involved with the regulation of myometrial activity independent of its effect on the ovarian production of steroid hormones. The physiological significance of myometrial $\mathrm{LH} / \mathrm{hCG}$ receptors during specific reproductive events, such as the oestrous cycle and pregnancy, remains to be determined.

We thank Dr G. D. Niswender (Colorado State Univ., Ft Collins, CO) for supplying the LH antiserum; Dr Leo Reichert (Albany Medical College, Albany, NY) for purified porcine LH; Dr D. J. Bolt, USDA Hormone Program, for purified porcine FSH and porcine FSH antisera; Dr R. C. Canfield, Center for Population Research, NICHHD, NIH, for the purified hCG; Dr N. R. Mason, Eli Lilly Laboratories (Indianapolis, IN) for the oestradiol-17 $\beta$ antisera; Dr Carol Vreeland for technical assistance; and Ms C. McKinney for secretarial assistance with the preparation of this manuscript.

The use of trade names in this publication does not imply endorsement by the North Carolina Agricultural Research Service of the products named, nor criticism of similar ones not mentioned. 


\section{References}

Armstrong, J.D. \& Britt, J.H. (1987) Nutritionallyinduced anestrus in gilts: metabolic and endocrine changes associated with cessation and resumption of estrous cycles. J. Anim. Sci. 65, 508 523.

Blandau, R.J. (1969) Gamete transport-comparative aspects. In The Mammalian Oviduct, p. 129. Eds E. S. E. Hafez \& R. J. Blandau. University of Chicago Press, Chicago.

Burton, K. (1956) A study of the conditions and mechanism of the diphenylamine reaction for the colorimetric estimation of deoxyribonucleic acid. Biochemistry, N.Y. 62, 3 I 5322.

Cahill, L.P., Knee, B.W. \& Lawson, R.A.S. (1976) Induction of parturition in ewes with a single dose of oestradiol benzoate. J. Reprod. Fert. 46, 528529.

Challis, J.R.G. \& Lye, S.J. (1986) Parturition. In Oxford Reviews of Reproductive Biology. Vol. 8, pp. 101- 105. Ed. J. R. Clarke. Oxford University Press, Oxford.

Cox, N.M. \& Britt, J.H. (1982) Pulsatile administration of gonadotropin releasing hormone to lactating sows: endocrine changes associated with induction of fertile estrus. Biol. Reprod. 27, 1126-1137.

Esbenshade, K.L. \& Britt, J.H. (1985) Active immunization of gilts against gonadotropin-releasing hormone: effects on secretion of gonadotropins, reproductive function and responses to agonists of gonadotropinreleasing hormone. Biol. Reprod. 33, 569577.

Finn, C.A. \& Porter, D.G. (1975) Mechanical activity: methodology and hormonal control. In The Uterus, pp. 173 236. Ed. C. A. Finn. Paul Elek (Scientific Books) Ltd., London.

Garverick, H.A., Polge, C. \& Flint, A.P.F. (1982) Oestradiol administration raises luteal $\mathrm{LH}$ receptor levels in intact and hysterectomized pigs. J. Reprod. Fert. 66, $371-377$.

Gimeno, M.F., Sterin-Speziale, N., Landa, A. Bonacossa, A. \& Gimeno, A.L (1979) Is the spontaneous motility of isolated rat uterus controlled by prostaglandin E? Prostaglandins 17, 673-683.

Guthrie, H.D. \& Bolt, D.J. (1983) Changes in plasma estrogen, luteinizing hormone, follicle-stimulating hormone and 13,14-dihydro-15-keto-prostaglandin F2 $\alpha$ during blockade of luteolysis in pigs after human chorionic gonadotropin treatment. J. Anim. Sci. 57, 993.

Hawk, H.W. (1973) Uterine motility and sperm transport in the estrous ewe after prostaglandin induced regression of corpora lutea. J. Anim. Sci. 37, 13801385.

Hawk, H.W. (1975) Enhancement by exogenous estradiol of uterine motility in estrous ewes. J. Anim. Sci. 41, 572-577.

Hawk, H.W. \& Cooper, B.S. (1974) Estrogen enhancement of sperm transport in ewes. J. Anim. Sci. 39, 210.

Hsueh, A.J.W., Adashi, E.Y., Jones, P.B.C. \& Welsh, T.H. (1984) Hormonal regulation of the differentiation of cultured ovarian granulosa cells. Endocr. Rev. 5, $76 \cdots 127$.

Huzar, G. (1983) Biology of the myometrium and cervix. In The Biological Basis of Reproductive and Developmental Medicine, pp. 101-112. Ed. J. R. Warshaw. Elsevier Biomedical, New York.
Jensen, J.D. \& Odell, W.D. (1988) ldentification of LH hCG receptors in rabbit uterus $(42775)$. Proc. Soc. exp. Biol. Med. 189, 28-30.

Kawarabayashi, T., Kishikawa, T. \& Sugimori, H. (1989) Effects of external calcium, magnesium and temperature on spontaneous contractions of pregnant human myometrium. Biol. Reprod. 40, 942-948.

Ketelslegers, J.M., Knott, G.D. \& Catt, K.J. (1975) Kinetics of gonadotropin binding by receptors of the rat testis. Analysis by a nonlinear curve-fitting method. Biochemistry, N.Y. 14, 30753083

Liggins, G.C., Fairclough, R.J., Grieves, S.A., Kendall, J.Z.K. \& Knox, B.S. (1973) The mechanism of initiation of parturition in the ewe. Recent Prog. Horm. Res. 29, 111-150.

Lowry, O.H., Rosebrough, N.J., Farr, A.L. \& Randall, R.J. (1951) Protein measurement with the Folin phenol reagent. J. biol. Chem. 193, 265-275.

Lye, S.J. \& Challis, J.R.G. (1982) Inhibition by $\mathrm{PGI}_{2}$ on myometrial activity in vivo in non-pregnant ovariectomized sheep. J. Reprod. Fert. 66, 311-315.

Lye, S.J. \& Porter, D.G. (1978) Demonstration that progesterone 'blocks' uterine activity in the ewe in vivo by direct action on the myometrium. J. Reprod. Fert. 52, 87-94.

Lye, S.J., Sprague, C.L. \& Challis, J.R.G. (1983a) Modulation of ovine myometrial activity by estradiol- $17 \beta$. The possible involvement of prostaglandins. Can. J. Physiol. Pharmacol. 61, 729.735.

Lye, S.J., Wathes, D.C. \& Porter, D.G. (1983b) Oestradiol$17 \beta$ both inhibits and stimulates myometrial activity in ewes in vivo. J. Reprod. Fert. 67, 335-341.

Pomp, D., Eisen, E.J. \& Ziecik, A.J. (1988) LH receptor induction and ovulation rate in mice selected for litter size and body weight. $J$. Reprod. Fert. 84, 601-610.

Pope, W.F., Maurer, R.R. \& Stormshak, F. (1982) Intrauterine migration of the porcine embryo: Interaction of embryo, uterine flushings and indomethacin on myometrial function in vitro. J. Anim. Sci. 55, 1169-1178.

Porter, D.G. \& Lye, S.J. (1983) Partial reversal of the myometrial progesterone 'block' in the non-pregnant ewe in vivo by oestradiol-17 $\beta$. J. Reprod. Fert. 67, 227-234.

Porter, D.G., Lye, S.J., Bradshaw, J.M.C. \& Kendall, J.Z.K. (1981) Relaxin inhibits myometrial activity in the ovariectomized non-pregnant ewe. $J$. Reprod. Fert. 61, 409-414.

Rexroad, C.E. \& Barb, C.R. (1975) Effect of prostaglandins on uterine contractions in the estrous ewe. Theriogenology 4, 111-124.

Rexroad, C.E. \& Barb, C.R. (1978) Contractile response of the uterus of the estrous ewe to adrenergic stimulation. Biol. Reprod. 19, 297-305.

Richards, J.S., Ireland, J.J., Rao, M.C., Bernath, G.A., Midgley Jr., A.R. \& Riechert. (1976) Ovarian follicular development in the rat: hormone receptor regulation by estradiol, follicle-stimulating hormone and luteinizing hormone. Endocrinology 99, 1562-1573.

Scatchard, G. (1949) The attraction of proteins for small molecules and ions. Ann. N.Y. Acad. Sci. 51, 660-672. 
Schwabe, C., Steinetz, B.G., Weiss, G., Segaloft, A., McDonald, J.K., O'Byrne, E., Hochman, J., Carrierre, B. \& Goldsmith, L. (1978) Relaxin. Recent Prog. Horm. Res. 34, 123.199.

Snedecor, G.W. \& Cochran, W.G. (1980) Statistical Methods, pp. 101-105. lowa State University Press, Ames.

Steel, R.G.D. \& Torrie, J.H. (1980) Principles and Procedures of Statistics: A Biomedical Approach, pp. 171-178. McGraw-Hill Book Co., New York.

Stevenson, J.S., Cox, N.M. \& Britt, J.H. (198I) Role of the ovary in controlling LH. FSH and prolactin secretion during and after lactation in pigs. Biol. Reprod. 24, 341-353.

Szlachter, N., O'Byrne, E., Goldsmith, L., Steinetz, B. \& Weiss, G. (1980) Myometrial inhibiting activity of relaxin-containing extracts of human corpora lutea of pregnancy. Am. J. Obstet. Gynec. 136, 584586.
Taverne, M.A.M. (1982) Myometrial activity during pregnancy and parturition in the pig. In Control of Pig Reproduction, pp. 419-436. Eds P. J. A. Cole \& G. R. Foxcroft. Butterworths, London.

Van de Wiel, D.F.M., Erkens, J., Koops W., Vos, E. \& Van Landeghem, A.A.J. (1981) Periestrous and midluteal time courses of circulating LH, FSH, prolactin, estradiol-17 $\beta$ and progesterone in the domestic pig. Biol. Reprod. 24, 223 233.

Wainman, B.C., Burcea, I. \& Crankshaw, D.J. (1988) The effects of prostanoids on estrogen-dominated rat longitudinal muscle in vitro. Biol. Reprod. 39, 221-228.

Ziecik, A.J., Stanchev, P.D. \& Tilton, J.E. (1986) Evidence for the presence of luteinizing hormone/human chorionic gonadotropin-binding sites in the porcine uterus. Endocrinology 119, 1159-1163.

Received 28 August 1990 